\title{
THE EFFECTS OF MILLING DEGREE AND TYPE OF BAG ONFUNGAL INFECTION AND SOME CHEMICAL CONTENTS OF STORED MILLED RICE
}

\author{
OKKY SETYAWATIDHARMAPUTRA \\ SEAMEOBIOTROP, P.O. Box 116, Bogor, Indonesia, and \\ Department of Biology, Faculty of Mathematics and Natural Sciences, Bogor Agricultural University, \\ Bogor, Indonesia
}

\begin{abstract}
The effects of milling degree and type of bag on fungal infection of stored milled rice were investigated together with some chemical contents (glucose, amylose, protein and total lipid contents), and changes in moisture content.

Rice var. IR 64 with different milling degrees (85,90, 95 and 100\%) packed in jute and polypropylene bags (1 kg of milled rice/bag) were stored under laboratory conditions with temperature between $24.3-27.3 \mathrm{C}$ and relative humidity 52.6-81.9\% for 3 months. The initial moisture content (m.c.) of milled rice was $\pm 14 \%$. Three replications ( 3 bags) were used for each treatment. Each bag was put individually and was arranged randomly on a wooden pallet.

The results showed that in general, the increase of milling degree and duration of storage decreased the m.c. Type of bag did not give significant differences on the m.c.

Twenty eight fungal species were isolated from rice with different milling degree and bag type during storage. The predominant species was Aspergillus Candidas. Total fungal population decreased with the increase of milling degree and duration of storage. Bag type did not give significant differences on total fungal population.

In general, the increase of milling degree increased glucose content. Glucose content in milled rice packed in jute bag was higher than that in polypropylene bag. Glucose content tended to decrease with the increase of storage duration.

The increase of milling degree increased amylose content in milled rice. Amylose content of milled rice packed in jute bag was lower than that in polypropylene bag. The increase of storage duration decreased amylose content in milled rice.

In general, protein content decreased with the increase of milling degree and duration of storage. 1 type did not give significant differences on protein content.

Total lipid content decreased with the increase of milling degree and duration of storage. Total lipid content of milled rice packed in jute bag was lower than that in polypropylene bag, but based on chemical analysis the difference was not significant.

Based on statistical analyses, correlation between the m.c. and total lipid content with total fungal population was positive. There was no correlation between glucose, amylose and protein contents with total fungal population.

Rice with high milling degree can be stored safely for long period, but it has low chemical (nutritional) contents.
\end{abstract}

Key words: Milling degree/Bag type/Fungal infection/Chemical content/Milled rice.

\section{INTRODUCTION}

Rice (Oryza saliva L.) is the primary foodcrop in Indonesia. The National Logistics Agency (BULOG) buys and stores a large amount of milled rice as national stock to maintain price stability. 
During storage rice could be infested by insects, mites, microorganisms and rodents. Among the microorganisms, fungi are the most important cause of deterioration of stored products (Christensen and Kaufmann 1974).

The tropical climate of Indonesia provides a favourable condition for fungal growth. According to Garraway and Evans (1984) the development of fungi was affected by the nutritional content of the substrate.

The degree of milling is one of the physical characters of rice that may influence the fungal development. Another factor that may affect the fungal development is the type of bag used to store milled rice.

The objective of the study is to get information on the effects of milling degrees and bag types on moisture content, fungal population, and some chemical contents (glucose, amylose, protein and total lipid) of milled rice during 3 months of storage.

\section{MATERIALS AND METHODS}

\section{Rice variety, milling degree, bag type, and storing of milled rice}

Rice var. IR 64 was used in this study, because it is widely cultivated in Indonesia. The paddy was obtained from Food Technology Research and Training Centre (Balai Penelitian Teknologi Pangan) BULOG, Tambun, and it was stored for 2 weeks from the harvest time.

The paddy was milled with different milling degrees, i.e. 85, 90, 95 and 100\%. Rice with $85 \%$ milling degree was enclosed by $15 \%$ of bran layer and embryo, while rice with $100 \%$ milling degree was die rice that had neither bran layer nor embryo (Juliano 1972; BULOG 1994). Two types of bag were used, i.e. jute and polypropylene bags.

Rice with milling degree of $85,90,95$ and $100 \%$ were stored in jute and polypropylene bags (1 $\mathrm{kg} / \mathrm{bag}$ ) under laboratory conditions for 3 months. The initial moisture content of milled rice was $\pm 14 \%$. Before storage rice was fumigated with phos-phine at dosage rates $2 \mathrm{~g} /$ tonne of rice for 6 days. Three replications (3 bags) were used for each treatment. Each bag was arranged randomly on a wooden pallet (Figure 1). During storage the temperature and the relative humidity of the storage were recorded using a thermohygrograph.

\section{Obtaining working samples}

Initial samples were obtained from each replication (bag) of treatment at the beginning of storage, and then at 1,2 and 3 months of storage. A sample from each bag was divided using a sample divider into 4 sub samples for (1) moisture content analysis, (2) fungal analysis, (3) some chemical content analyses, and (4) reserve sample. 


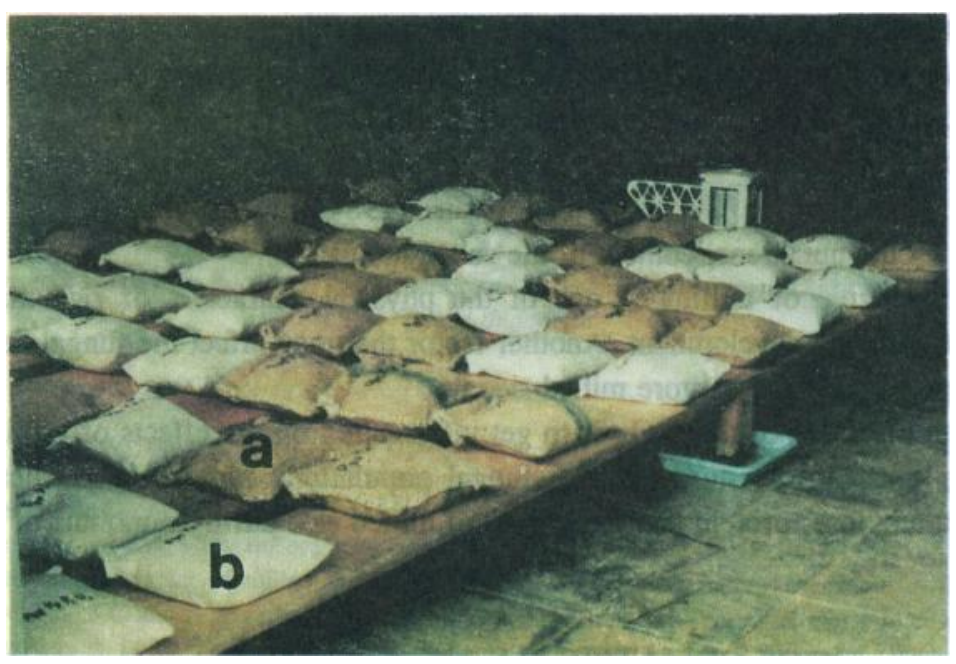

Figure 1. Milled rice packed in jute (a) and polypropylene (b) bags, and arranged randomly on a wooden pallet.

\section{Moisture content, fungal and chemical content analyses}

Moisture content was determined using an oven method (BSI 1980). Fungi were isolated using dilution method on Dichloran 18\% Glycerol Agar (DG 18) (Pitt and Hocking 1985). The glucose, amylose, protein and total lipid contents were determined using modified Anthrone, Williams, Kjeldahl and Soxhlet extraction methods, respectively (Yoshida et al. 1976).

\section{Identification of the fungi}

Fungal identification was carried out according to Samson et al. (1984), Pitt and Hocking (1985).

Experimental data were analysed using Completely Randomized Factorial Design with 3 factors. The 1st, 2nd, and 3rd factors were milling degree, type of bag, and duration of storage, respectively.

\section{RESULTS AND DISCUSSIONS}

\section{Moisture content}

Moisture content (m.c.) is the most important factor in determining the development of microorganism, insect and chemical reaction hi stored products (Muir 1973; Sinha 1973). 
Based on statistical analysis, milling degree, duration of storage, interaction between bag types and duration of storage, interaction among milling degree, bag types and duration of storage gave very significant differences on the m.c., while interaction between milling degree and bag type was significantly different. Type of bag and interaction between milling degree and duration of storage were not significantly different.

The increase of milling degree decreases the m.c. (Table 1). The m.c of rice with 85, 90, 95, and $100 \%$ milling degree were $14.18,14.04,13.91$ and $13.73 \%$, respectively.

Table 1. The effect of milling degree, duration of storage, interaction between milling degree and bag type, interaction between bag type and duration of storage, and interaction among milling degree, bag type, and duration of storage on moisture content of rice

\begin{tabular}{|c|c|c|c|c|c|c|c|c|c|c|c|}
\hline \multirow{3}{*}{$\frac{\begin{array}{c}\text { Milling } \\
\text { degree }(\%)\end{array}}{85}$} & \multirow{4}{*}{$\begin{array}{c}\text { Bag cype } \\
\begin{array}{c}\text { Jute } \\
\text { Polypropylene }\end{array}\end{array}$} & \multicolumn{10}{|c|}{ Moisture content (\%) } \\
\hline & & \multicolumn{10}{|c|}{ Duration of storage (month) } \\
\hline & & \multicolumn{2}{|c|}{0} & \multicolumn{2}{|c|}{$\mathbf{I}$} & \multicolumn{2}{|c|}{2} & \multicolumn{2}{|c|}{3} & \multicolumn{2}{|c|}{$\overline{\mathbf{x}}$} \\
\hline 85 & & $\begin{array}{l}14.59 \\
14.59\end{array}$ & $\begin{array}{l}0 \\
0\end{array}$ & $\begin{array}{l}14.34 \\
14.50\end{array}$ & $\begin{array}{l}\text { op } \\
\text { o }\end{array}$ & $\begin{array}{l}13.83 \\
13.96\end{array}$ & $\begin{array}{l}\text { qrst } \\
\text { pqr }\end{array}$ & $\begin{array}{l}13.78 \\
13.85\end{array}$ & $\begin{array}{l}\text { rstu } \\
\text { qrs }\end{array}$ & $\begin{array}{l}14.13 \\
14.22 \\
14.18\end{array}$ & $\begin{array}{l}\text { h } \\
\text { h } \\
\text { a }\end{array}$ \\
\hline 90 & $\begin{array}{c}\text { Jute } \\
\text { Polypropylene }\end{array}$ & $\begin{array}{l}14.51 \\
14.51\end{array}$ & $\begin{array}{l}0 \\
0\end{array}$ & $\begin{array}{l}14.44 \\
14.01\end{array}$ & $\stackrel{\circ}{\text { pqr }}$ & $\begin{array}{l}13.68 \\
13.63\end{array}$ & $\begin{array}{l}\text { rstu } \\
\text { rstu }\end{array}$ & $\begin{array}{l}13.78 \\
13.76\end{array}$ & $\begin{array}{l}\text { rsn } \\
\text { rstu }\end{array}$ & $\begin{array}{l}14.10 \\
13.98 \\
14.04\end{array}$ & $\begin{array}{l}\text { h } \\
\text { hi } \\
b\end{array}$ \\
\hline 95 & $\begin{array}{c}\text { Jute } \\
\text { Polypropylene }\end{array}$ & $\begin{array}{l}14.35 \\
14.35\end{array}$ & $\begin{array}{l}o p \\
o p\end{array}$ & $\begin{array}{l}14.22 \\
13.82\end{array}$ & $\begin{array}{l}\text { ops } \\
\text { qrst }\end{array}$ & $\begin{array}{l}13.41 \\
13.66\end{array}$ & $\begin{array}{l}\text { ru } \\
\text { rsms }\end{array}$ & $\begin{array}{l}13.62 \\
13.83\end{array}$ & $\begin{array}{l}\text { rstu } \\
\text { qrst }\end{array}$ & $\begin{array}{l}13.90 \\
13.92 \\
13.91\end{array}$ & $\begin{array}{l}\mathrm{i} \\
\mathrm{i} \\
\mathrm{c}\end{array}$ \\
\hline 100 & $\begin{array}{c}\text { Jute } \\
\text { Polypropylene }\end{array}$ & $\begin{array}{l}14.19 \\
14.19\end{array}$ & $\begin{array}{l}\text { opq } \\
\text { opq }\end{array}$ & $\begin{array}{l}13.86 \\
13.88\end{array}$ & $\begin{array}{l}q r \\
q r\end{array}$ & $\begin{array}{l}13.40 \\
13.39\end{array}$ & $\begin{array}{l}u \\
u\end{array}$ & $\begin{array}{l}13.49 \\
13.44\end{array}$ & $\begin{array}{l}\text { stu } \\
\text { tu }\end{array}$ & $\begin{array}{l}13.73 \\
13.73 \\
13.73\end{array}$ & $\begin{array}{l}\mathrm{j} \\
\mathrm{j} \\
\mathrm{d}\end{array}$ \\
\hline $\bar{y}$ & $\begin{array}{c}\text { Jute } \\
\text { Polypropylene }\end{array}$ & $\begin{array}{l}14.41 \\
14.41 \\
14.41\end{array}$ & $\begin{array}{l}k \\
k \\
c\end{array}$ & $\begin{array}{l}14.22 \\
14.05 \\
14.13\end{array}$ & $\begin{array}{l}\text { I } \\
\text { n } \\
\text { f }\end{array}$ & $\begin{array}{l}13.58 \\
13.62 \\
13.62 \\
\end{array}$ & $\begin{array}{l}m \\
m \\
g\end{array}$ & $\begin{array}{l}13.67 \\
13.72 \\
13.69\end{array}$ & $\begin{array}{l}m \\
m \\
g\end{array}$ & & * \\
\hline
\end{tabular}

Numbers followed by the same letter do not differ significantly according to Tukey Multiple Range Test at 95\% confidence level

* not significantly different

According to Dharmaputra et al. (1993) the increase in milling degree increased the m.c. of milled rice that was stored under laboratory conditions for 3 months with temperature of $25 \pm 2 \mathrm{C}$ and relative humidity $(\mathrm{RH})$ of $80 \pm 5 \%$. In this study the result was not the same; the increase of milling degree decreased the m.c. It was assumed that the milled rice was stored at higher temperature (24.3-27.3 C) and lower RH (52.6-81.9\%) (Table 2). 
Table 2. Range of temperature and relative humidity at storage condition

\begin{tabular}{ccc}
\hline \hline $\begin{array}{c}\text { Duration of storage } \\
\text { (month) }\end{array}$ & $\begin{array}{c}\text { Temperature } \\
\text { (C) }\end{array}$ & $\begin{array}{c}\text { Relative humidity } \\
(\%)\end{array}$ \\
\hline 1 & $24.6-27.3$ & $57.0-77.1$ \\
2 & $24.3-27.3$ & $52.6-77.3$ \\
3 & $24.3-27.3$ & $52.6-81.9$ \\
\hline
\end{tabular}

The endosperm and the embryo of milled rice were enclosed by bran layer. The layer consists of pericarp, legmen and aleuron (Figure 2). The three layers contain more lipid and protein than the endosperm, while the latter contains more carbohydrate. The higher milling degree causes the higher loss of the three layers. Water could be easily bound by carbohydrate compared to lipid or protein. It was assumed that the high temperature and the low RH during storage caused the evaporation of water in the grain.

Although the pores of polypropylene bag was smaller than jute bag, type of bag did not give a significant difference on the m.c. It was assumed that only one bag (with $1 \mathrm{~kg}$ of rice) was put on the wooden pallet, so that air circulation did not affect the m.c. of rice.

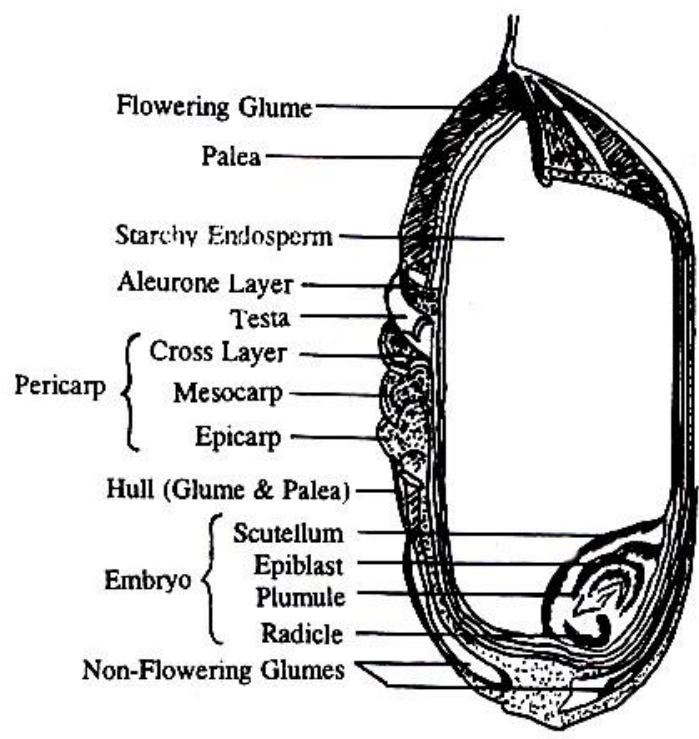

Figure 2. Structure of the rice grain (cited from Grist, 1969). 
During storage the m.c. of rice decreased, although the m.c. of rice at 2 months of storage was not significantly different from that at 3 months of storage (Table 1 ). This was probably because of the higher temperature and the lower RH during storage.

The lowest m.c. was found in rice with milling degree of $100 \%$ packed in polypropylene bag at 2 months of storage (13.39\%); while the highest was in rice with milling degree of $85 \%$ packed in jute and polypropylene bags at the beginning of storage ( $14.59 \%$ respectively).

\section{Species and fungal population}

Twenty eight species of fungi were isolated from rice with different milling degrees and bag types during storage. They were Aspergillus candidus, A. flavus, A. fumigatus, A. niger, A. oryiae, A. penicilloides, A. sydowii, A. terreus, A. versicolor, A. wentii, Cladosporium cladosporioides, Curvularia lunala, Eurotium chevalieri, E. repens, Endomyces fibuliger, Fusarium moniliforme, Nigrospora oryzae, Paecilomyces varotii, Penicillium sp. nr. adametzioides, P. chrysogenum, P. citrinum, P. corylo-philum, P. herquei, P. islandicum, $P$. raistrickii, Rhizopus microsporus, Synce-palastrum racemosum and Wallemia sebi. The predominant fungus was $A$. candidus. It was assumed that the m.c. of milled rice during storage was suitable for its growth, or the fungus was able to compete with other fungal species in colonizing the substrate.

Among the above species, there were some species of field fungi i.e. Cladosporium cladosporioides, Curvularia lunata, F. moniliforme, and $N$. oryzae. It was assumed that the fungi infected the grain before harvest and they survived during storage. According to Christensen and Kaufmann (1969) field fungi need m.c. in equilibrium with the high RH (90\%) or more for their growth.

The presence of each fungal species on rice with different milling degree during storage is presented in Table 3. A. candidus, C. cladosporioides and P.. citrinum were always isolated, while A. flavus and E. chevalieri were often isolated.

Most of the fungi isolated belong to genera Aspergillus, Eurotium, and Penicillium. According to Christensen and Kaufmann (1974) fungi that belong to genera Aspergillus and Penicillium caused deterioration in grain during storage. Pitt and Hocking (1985) reported that Eurotium is a teleomorph stage of Aspergillus which is a xerophilic fungus.

Based on statistical analysis, milling degree, duration of storage, and interaction between milling degree and duration of storage gave very significant differences on total fungal population, while bag type, interaction between milling degree and bag type, interaction between bag type and duration of storage, and interaction among milling degree, bag type, and duration of storage were not significantly different. 
Table 3. The presence of each fungal species on rice with different milling degree during storage

\begin{tabular}{|c|c|c|c|c|c|c|c|c|c|c|c|c|c|c|c|c|}
\hline \multirow{4}{*}{ Fungi } & \multicolumn{16}{|c|}{ Milling degree $(\%)$} \\
\hline & \multicolumn{4}{|c|}{85} & \multicolumn{3}{|c|}{90} & \multicolumn{5}{|c|}{95} & \multicolumn{4}{|c|}{100} \\
\hline & \multicolumn{16}{|c|}{ Duration of storage (month) } \\
\hline & 0 & 1 & 2 & 3 & 0 & 1 & 2 & 3 & 0 & 1 & 2 & 3 & 0 & 1 & 2 & 3 \\
\hline Aspergillus candidus & + & + & + & + & + & + & + & + & + & + & + & + & + & + & + & + \\
\hline A. flavus & + & + & + & + & + & + & + & + & + & + & + & + & + & + & + & + \\
\hline A. fumigatus & + & + & + & + & + & + & - & + & - & - & + & + & - & - & + & + \\
\hline A. niger & $=$ & + & - & - & - & - & - & - & - & - & - & - & + & + & - & - \\
\hline A. oryzae & - & + & - & - & - & - & - & - & + & - & - & - & + & - & - & - \\
\hline A. penicilloides & - & + & + & + & + & + & + & - & + & - & - & + & - & + & + & + \\
\hline A. sydowii & + & - & - & $\cdot$ & $=$ & $=$ & - & + , & - & - & - & + & + & + & + & - \\
\hline A. terreus & - & - & $\cdot$ & - & - & - & - & $\cdot$ & + & - & $\cdot$ & - & - & - & - & - \\
\hline A. versicolor & + & + & + & + & + & + & + & + & - & + & + & - & + & - & - & + \\
\hline A. wentii & - & + & - & - & - & - & - & - & - & - & - & + & - & - & - & + \\
\hline \multicolumn{17}{|l|}{ Cladosporium } \\
\hline cladosporioides & + & + & + & + & + & + & + & + & + & + & + & + & + & + & + & + \\
\hline Curvularia lunata & - & + & + & + & - & + & - & + & - & + & - & + & $\therefore$ & - & + & - \\
\hline Eurotium chevalieri & + & + & + & + & + & + & + & + & + & + & + & + & + & - & + & + \\
\hline E. repens & - & + & - & - & + & - & - & - & - & - & - & - & - & - & - & - \\
\hline Endomyces fibuliger & - & + & + & - & - & + & - & - & - & + & - & - & - & - & - & - \\
\hline Fusarium moniliforme & - & - & - & + & - & - & - & - & - & + & - & - & - & + & - & - \\
\hline Nigrospora onzzae & + & + & - & + & - & + & - & - & + & - & - & - & - & + & + & + \\
\hline $\begin{array}{l}\text { Paecilomyces varotii } \\
\text { Penicillium }\end{array}$ & \multicolumn{15}{|c|}{ Penicillium } & - \\
\hline chrysogenum & $\cdot$ & $\cdot$ & + & - & $=$ & - & + & - & + & - & - & - & - & - & - & $\cdot$ \\
\hline$P$. citrinum & + & + & + & + & + & + & + & + & + & + & + & + & + & + & + & + \\
\hline P. corylophilum & - & - & - & - & - & - & - & $=$ & - & - & - & - & - & + & - & - \\
\hline P. herquei & $\cdot$ & + & + & - & - & $=$ & - & - & - & $\cdot$ & - & - & - & - & - & $\cdot$ \\
\hline P. islandicum & $\cdot$ & - & - & - & - & - & $=$ & + & $=$ & + & - & + & - & - & - & $\cdot$ \\
\hline P. raistrickii & - & + & + & + & - & + & + & + & - & - & - & + & - & - & - & + \\
\hline \multicolumn{17}{|l|}{ Penicillium sp. nr. } \\
\hline Rhizopus microsporus & - & - & + & + & - & + & . & 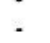 & + & - & 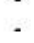 & 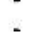 & - & 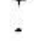 & . & 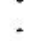 \\
\hline \multicolumn{17}{|l|}{ Syncephalastrum } \\
\hline racemosum & + & + & + & - & + & $\cdot$ & + & $\cdot$ & + & - & - & - & - & $\cdot$ & - & - \\
\hline Wallemia sebi & - & + & - & + & - & - & - & - & - & - & - & - & - & - & . & - \\
\hline
\end{tabular}

Total fungal population (transformed into $\log x$ ) on rice with milling degree of 85,90 , 95 and 100\% during 3 months of storage were 2.94, 2.50, 2.08 and 1,73 colonies/g, respectively (Table 4). Total fungal population decreased with the increase of milling degree. The total fungal population was related to the nutritional content of the rice. Protein, lipid, some organic acids, and vitamins decreased with the increase of milling degree. They are micro and macro-elements needed for fungal growth. According to Juliano (1972) the nutritional content of the rice with high milling degree was low because the outer layer of the rice was removed during milling, consequently a part of the nutrition found in this layer was lost. 
Table 4. The effect of milling degree, bag type, duration of storage, and interaction between milling degree and duration of storage on total fungal population of nee

\begin{tabular}{|c|c|c|c|c|c|c|c|c|c|c|c|}
\hline \multirow{4}{*}{$\begin{array}{l}\text { Milling } \\
\text { degree (\%) }\end{array}$} & \multirow{4}{*}{ Bag type } & \multicolumn{10}{|c|}{ Total furgal population (colonies/g) } \\
\hline & & \multicolumn{5}{|c|}{ Transformed into $\log x$} & \multicolumn{5}{|c|}{ Nod transformed into $\log x$} \\
\hline & & \multicolumn{5}{|c|}{ Duration of storage (month) } & \multicolumn{5}{|c|}{ Duration of storage (month) } \\
\hline & & 0 & 1 & 2 & 3 & $\overline{\mathbf{x}}$ & 0 & 1 & 2 & 3 & $\overline{\mathbf{x}}$ \\
\hline $\begin{array}{c}85 \\
90 \\
95 \\
100 \\
\bar{y}\end{array}$ & $\begin{array}{l}\text { Jutc } \\
\text { Polypropylene }\end{array}$ & $\begin{array}{c}312 \mathrm{i} \\
2.80 \mathrm{ij} \\
2.43 \mathrm{jk} \\
1.95 \mathrm{kl} \\
*^{*} \\
2.57 \mathrm{f}\end{array}$ & $\begin{array}{c}3.00 \mathrm{i} \\
2.54 \mathrm{jk} \\
2.17 \mathrm{jk} \\
1.90 \mathrm{kl} \\
\vdots \\
2.40 \mathrm{~g}\end{array}$ & $\begin{array}{c}3.02 \mathrm{i} \\
2.54 \mathrm{jk} \\
1.68 \mathrm{I} \\
1.61 \mathrm{~lm} \\
\bar{*}^{*} \\
2.21 \mathrm{~h}\end{array}$ & $\begin{array}{c}2.62 \mathrm{j} \\
2.13 \mathrm{k} \\
2.06 \mathrm{kl} \\
1.47 \mathrm{~m} \\
* \\
* \\
2.07 \mathrm{~h}\end{array}$ & $\begin{array}{l}2.94 \mathrm{a} \\
2.50 \mathrm{~b} \\
2.08 \mathrm{c} \\
1.73 \mathrm{~d} \\
2.28 \mathrm{c} \\
2.35 \mathrm{c}\end{array}$ & $\begin{array}{c}1505.92 \\
681.08 \\
313.42 \\
101.50 \\
* \\
* \\
650.48\end{array}$ & $\begin{array}{c}1040.92 \\
365.08 \\
152.42 \\
84.75 \\
: \\
410.79\end{array}$ & $\begin{array}{r}1081.00 \\
378.50 \\
59.33 \\
41.75 \\
* \\
* \\
390.15\end{array}$ & $\begin{array}{c}423.92 \\
143.17 \\
136.00 \\
32.17 \\
* \\
{ }^{*} \\
183.81\end{array}$ & $\begin{array}{r}1012.94 \\
391.96 \\
165.29 \\
65.04 \\
363.88 \\
453.96\end{array}$ \\
\hline
\end{tabular}

Numbers followed by the same letter do not differ significantly according to Tukey Multiple Range Test at 95\% confidence level

* Not significantly different

Type of bag did not give a significant difference on the total fungal population (Table 4). The m.c. is the environmental factor in determining the fungal growth and type of bag did not give a significant difference on it, so that the bag type did not also give a significant difference on total fungal population.

Total fungal population decreased with the increase of storage duration (Table 4). The total fungal population (transformed into $\log \mathrm{x}$ ) at the beginning of storage was significantly different from that at 1, 2 and 3 months of storage, while after 2 and 3 months of storage they were not significantly different, although their population tended to decrease. The decrease of total fungal population was presumably related to the decrease of nutritional and moisture contents in rice. The total fungal population (not transformed into $\log \mathrm{x}$ ) at the beginning of storage, and at 1,2 and 3 months of storage were $650.48,410.79,390.15$ and 183.81 colonies/g, respectively.

The lowest total fungal population was found in rice with milling degree of $100 \%$ after 3 months of storage (32.17 colonies/g), while the highest was in rice with milling degree of $85 \%$ at the beginning of storage ( 1505.92 colonies/g).

\section{Fungi in rice with milling degree of $85 \%$}

BULOG (1994) determined that rice with $85 \%$ milling degree was enclosed by $15 \%$ of bran layer and embryo.

Twenty four fungal species were isolated from rice with $85 \%$ milling degree at the beginning of storage, and at 1,2, and 3 months of storage. They were Aspergillus candidus, A. flavus, A. fumigatus, A. niger, A. oryzae, A. penicilloides, A. sydowii, A. versicolor, A. wentii, Cladosporium dadosporioides, Curvularia lunata, Eurotium 
chevalieri, E. repens, Endomyces fibuliger, Fusarium moniliforme, Nigrospora oryzae, Penicillium sp. nr. adametzioides, $P$. chrysogenum, $P$. citrinum, $P$. herquei, $P$. raistrickii, Rhizopus microsporus, Syncephalastrum racemosum and Wallemia sebi. Population of each fungal species is presented in Table 5 .

Fungal species at the beginning of storage, and at 1,2, and 3 months of storage were dominated by $A$. candidus with the population of $1474.33,947.67,1045.59$ and 372.09 colonies/g, respectively.

\section{Fungi in rice with milling degree of $90 \%$}

BULOG (1994) determined that rice with $90 \%$ milling degree was enclosed by $10 \%$ of bran layer and embryo.

Twenty one fungal species were isolated from rice with $90 \%$ milling degree at the beginning of storage, and at 1,2, and 3 months of storage. They were Aspergillus candidus, A. flavus, A. fumigatus, A. penicilloides, A. sydowii, A. terreus, A. ver-sicolor, Cladosporium dadosporioides, Curvularia lunata, Eurotium chevalieri, E. re-pens, Endomyces fibuliger, Nigrospora oryzae, Paecilomyces varotii, Penicillium sp, nr. adametzioides, P. chrysogenum, $P$. citrinum, $P$. islandicum, $P$. raistrickii, Rhizopus microsporus and Syncephalastrum racemosum. Population of each fungal species is presented in Table 5.

Fungal species at the beginning of storage, and at 1,2, and 3 months of storage were dominated by $A$. candidus with the population of $656.08,332.41,355.83$ and 84.67 colonies/g, respectively.

Dharmaputra (1994) reported that milled rice with the same variety (IR 64) and milling degree (90\%) stored for 3 months under laboratory conditions (in jars), was infected by eleven fungal species i.e. A. candidus, A. flavus, A. niger, A. penicilloides, A. versicolor, A. wentii, $C$. dadosporioides, E. chevalieri, E. repens, $P$. citrinum and $P$. herquei. The predominant species was $A$. flavus. The difference in fungal species that infected milled rice was presumably due to the difference of location where the paddy was cultivated.

Fungi in rice with milling degree of $95 \%$

BULOG (1994) determined that rice with $95 \%$ milling degree was enclosed by $5 \%$ of bran layer and embryo.

Twenty two fungal species were isolated from rice with $95 \%$ milling degree at the beginning of storage, and at 1, 2, and 3 months of storage. They were Aspergillus candidus, $A$. flavus, A. fumigatus, A. oryzae, A. penicilloides, A. sydowii, A. terreus, 
The effects of milting degree and type of bag on fungal infection - Okky Setyawati Dharmapuera

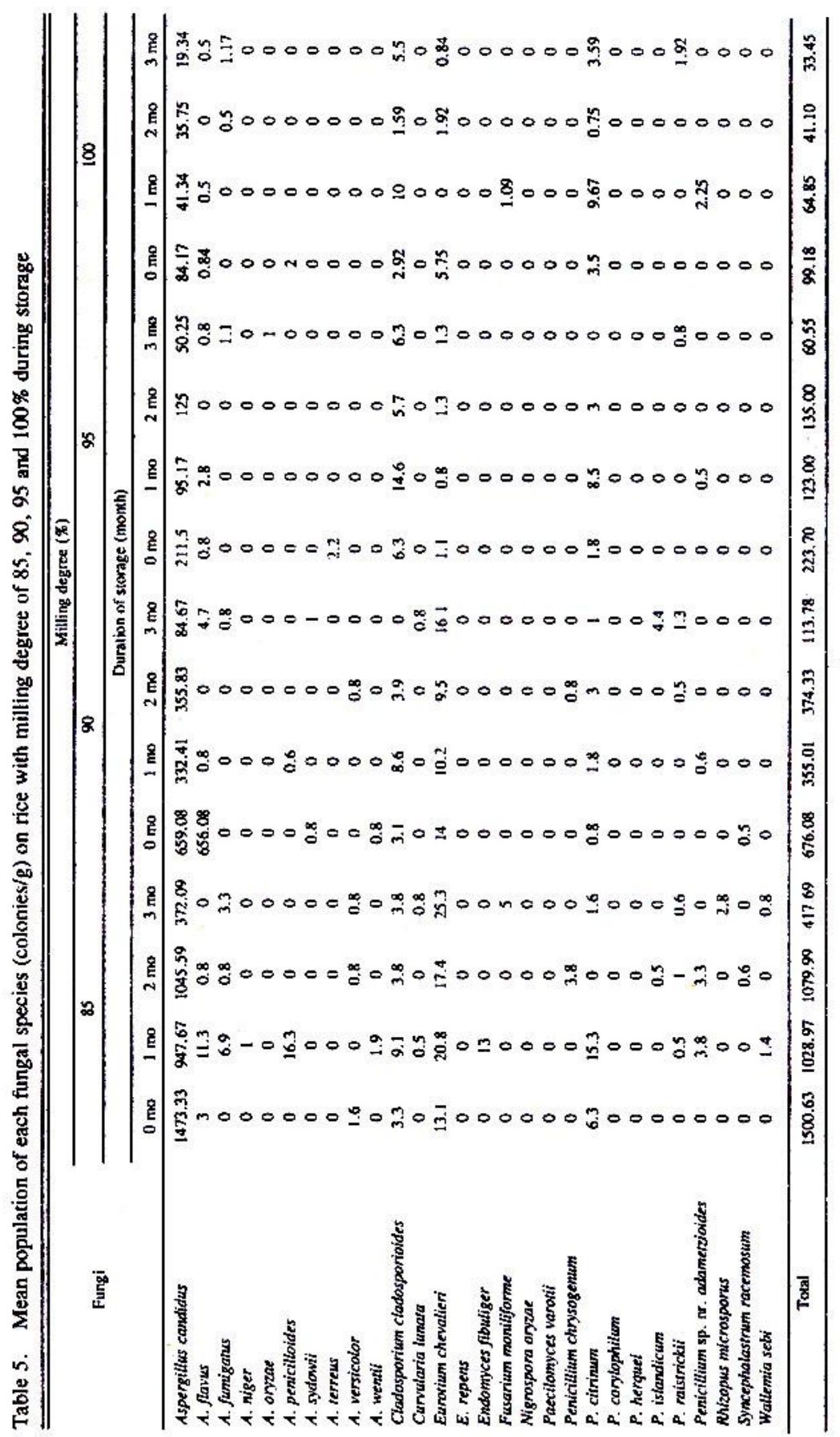


A. versicolor, Cladosporium cladosporioides, Curvularia lunata, Eurotium chevalieri, Endomyces fibuliger, Fusarium moniliforme, Nigrospora oryzae, Paecilomyces varotii, Penicillium sp. nr. adametzioides, P. chrysogenum, P. citrinum, P. islandicum, P. raistrickii, Rhizopus microsporus and Syncephalastrum racemosum. Population of each fungal species is presented in Table 5.

Fungal species at the beginning of storage, and at 1, 2, and 3 months of storage were dominated by $A$. Candidas with the population of $211.50,95.17,125.00$ and 50.25 colonies/g, respectively.

\section{Fungi in rice with milling degree of $100 \%$}

Rice with $100 \%$ milling degree had neither bran layer nor embryo. It had only an endosperm (Juliano 1972; BULOG 1994).

Eighteen fungal species were isolated from rice with $100 \%$ milling degree at the beginning of storage, and at 1,2, and 3 months of storage. They were Aspergillus Candidas, A. flavus, A. fumigatus, A. niger, A. oryzae, A. penicilloides, A. sydowii, A, versicolor, A. wentii, Cladosporium cladosporioides, Curvularia lunata, Eurotium chevalieri, Fusarium moniliforme, Nigrospora oryzae, Penicillium sp. nr. adametzioides, $P$. citrinum, $P$. corylophilum, and P. raistrickii, Population of each fungal species is presented in Table 5.

Fungal species at the beginning of storage, and at 1,2, and 3 months of storage were dominated by $A$. Candidas with the population of $84.17,41.34,35.75$ and 19.34 colonies/g, respectively.

\section{Glucose content}

Most of fungi use glucose (D-glucose) for their growth (Moore-Landecker 1982). Glucose is a form of monosaccharide with six carbon atoms (hexose). Mono-saccharide is considered as carbohydrate which cannot be hydrolized into a simple form and has a very simple bond compared to polysaccharide. Consequently, their chemical bond can be easily separated by enzymes compared to amylose, a polysaccharide which has a more complex chemical bond than monosaccharide (Mayes 1981).

Based on statistical analysis, milling degree, bag type, duration of storage, interaction between milling degree and bag type, and interaction among milling degree, bag type and duration of storage gave very significant differences on the glucose content, while interaction between milling degree and duration of storage was no! significantly different. Interaction between bag type and duration of storage was noi significantly different. 
Glucose content increased with the increase of milling degree (Table 6). The higher milling degree caused the higher loss of the bran layer and embryo. Therefore, the percentage (w/w) of glucose content in rice with high milling degree was higher than that of low milling degree. Glucose content on rice with milling degree of $85,90,95$ and $100 \%$ were 2.99, 3.50, 3.27 and $3.41 \%$, respectively.

Milled rice packed in jute bag had glucose content higher than packed in polypropylene bag. It was assumed that total fungal population in milled rice packed in jute bag was lower than in polypropylene bag, although based on statistical analysis it was not significantly different (Table4).

Glucose content tended to decrease with the increase of storage duration. It was attributed that the glucose was used for the fungal growth (Moore-Landecker 1982) and as energy source for grain respiration (Pomeranz 1992). Glucose content at the beginning and one month of storage were significantly different from that at 2 and 3 months of storage. The glucose content of milled rice at the beginning of storage, and at 1,2 , and 3 months of storage were 3.74 , $3.86,2.84$ and $2.73 \%$, respectively.

Table 6. The effect of milling degree, bag type, duration of storage, interaction between milling degree and bag type, interaction between nulling degree and duration of storage, and interaction among milling degree, bag type and duration of storage on glucose content of rice.

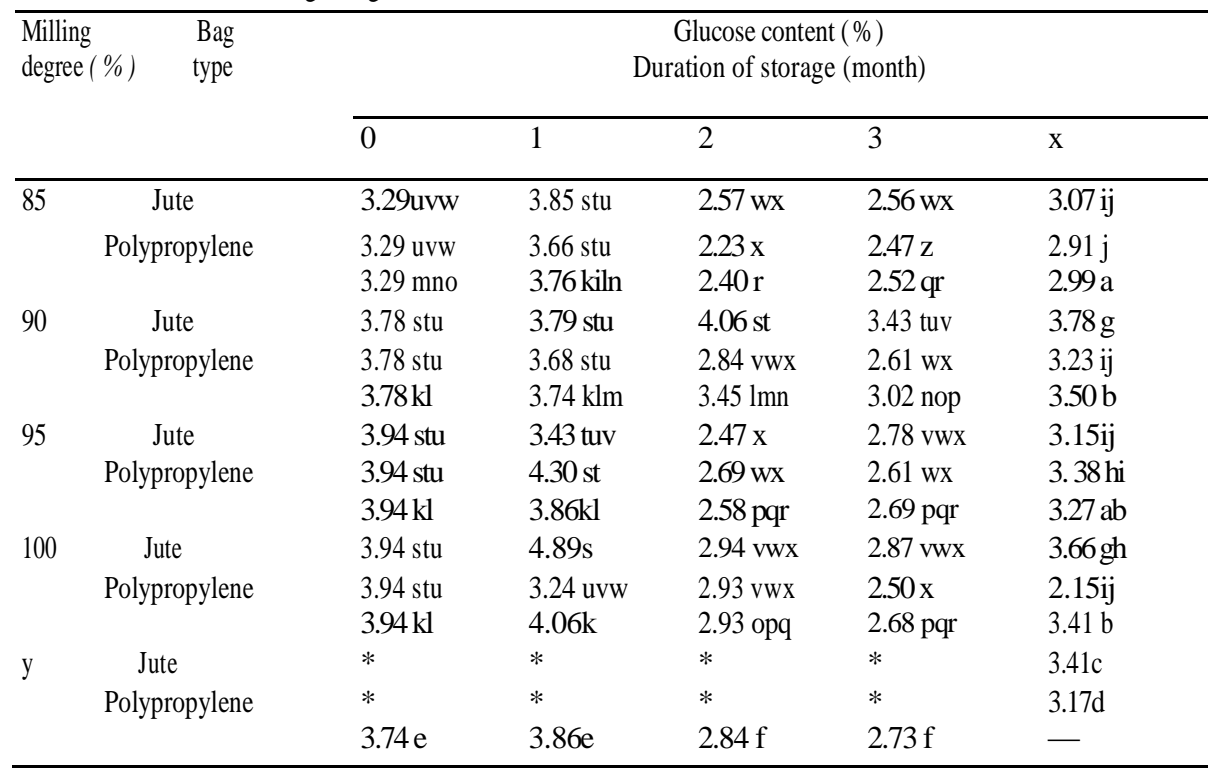

Numbers followed by the same letter do not differ significantly according to Tukey Multiple Range Test at $95 \%$ confidence level

*Not significantly different 
The highest glucose content was found in rice with milling degree of $100 \%$ packed in jute bag at one month of storage (4.89\%), while the lowest was in rice with milling degree of $85 \%$ packed in polypropylene bag at 2 months of storage $(2.23 \%)$.

Although a sugar other than glucose may give maximum growth of a fungus, it appears that the more closely the configuration of a sugar resembles glucose, the more fungi use it. This might be due to the ability of a fungus to use a particular sugar depending on how easy it can be converted into a phosphorylated derivative of glucose which can enter the respiratory pathways (Moore-Landecker 1982).

\section{Amylose content}

Most of the carbohydrate found in rice is in the form of starch (90\% of dry weight) and only a very small part is in the form of hemicellulose, cellulose and some free sugars such as sucrose, raffinose, glucose and fructose (Juliano 1972).

Starch is a polysaccharide that can be separated into two fractions depending on their ability to dissolve hi water, that is amylose $( \pm 20 \%)$ and amylopectin $( \pm 80 \%)$ (Mayes 1981).

Juliano (1972) reported that based on dry weight, the amylose content of milled rice was between $7-33 \%$ depending on rice variety.

Based on statistical analysis, milling degree and duration of storage gave very significant differences on the amylose content, while bag type gave a significant difference. Interaction between milling degree and bag type, interaction between milling degree and duration of storage, interaction between bag type and duration of storage, and interaction among milling degree, bag type and duration of storage did not give significant differences.

The increase of milling degree increased amylose content $(\mathrm{w} / \mathrm{w})$ in milled rice. The amylose content of milled rice with milling degree of 85, 90, 95 and 100\% were 23.84, 23.99. 24.98 and $25.50 \%$, respectively (Table 7).

Amylose content of milled rice packed in jute bag (24.09\%) was lower than that in polypropylene bag (25.07\%). It was assumed that the pores of jute bag was bigger than that of polypropylene bag, so that the air surrounding jute bag could make easier to hydrolize the amylose to form maltose or glucose.

The increase of storage duration decreased amylose content in milled rice. The amylose content at the beginning of storage, and at 1, 2 and 3 months of storage were 26.72, 25.40, 24.29 and $21.90 \%$, respectively. Presumably the phenomena was due to the activities of (3-amylase and fungal enzymes which infected the molecule a-glucans and supported the hydrolization of amylose to disaccharide and mono- saccharide. 
The effects of milling degree and type of bag on fungal infection - Okky Setyawati Dharmaputra

Table 7. The effect of milling degree, bag type, and duration of storage on amylose content of rice

\begin{tabular}{|c|c|c|c|c|c|c|}
\hline \multirow{3}{*}{$\begin{array}{l}\text { Milling } \\
\text { degree }(\%)\end{array}$} & \multicolumn{6}{|c|}{ Amylose content (\%) } \\
\hline & \multirow{2}{*}{$\begin{array}{l}\text { Bag } \\
\text { type }\end{array}$} & \multicolumn{4}{|c|}{ Duration of storage (month) } & \multirow[b]{2}{*}{$\mathrm{X}$} \\
\hline & & 0 & 1 & 2 & 3 & \\
\hline 85 & & $*$ & $*$ & * & * & $23.84 \mathrm{a}$ \\
\hline 90 & & $*$ & $*$ & $*$ & $*$ & $23.99 \mathrm{ab}$ \\
\hline 95 & & $*$ & $*$ & * & $*$ & 24.98 be \\
\hline 100 & & $*$ & $*$ & $*$ & $*$ & $25.50 \mathrm{c}$ \\
\hline \multirow[t]{3}{*}{ y } & Jute & $*$ & $*$ & $*$ & $*$ & $24.09 \mathrm{~d}$ \\
\hline & Polypropylene & $*$ & $*$ & $*$ & $*$ & $25.07 \mathrm{e}$ \\
\hline & & $26.72 \mathrm{f}$ & $25.40 \mathrm{~g}$ & $24.29 \mathrm{~h}$ & $21.90 \mathrm{i}$ & \\
\hline
\end{tabular}

Numbers followed by the same letter do not differ significantly according to Tukey Multiple Range Test at $95 \%$ confidence level

* Not significantly different

\section{Protein content}

Rice is one of the cereals which contains a higher percentage of lysine $( \pm 4 \%)$ than other cereals. Lysine is an essential amino acid which is found in very small quantities in other food stuff (Juliano et al. 1973).

Brown rice contained $\pm 8 \%$ protein, $75 \%$ carbohydrate and a small amount of lipid, fibre and ash, while milled rice contained $\pm 7 \%$ protein (Juliano 1976).

Based on statistical analysis, milling degree and duration of storage gave very significant differences on the protein content, while interaction between milling degree and duration of storage was significantly different. Bag type, interaction between milling degree and bag type, interaction between bag type and duration of storage, and interaction among milling degree, bag type and duration of storage did not give significant differences.

The protein content tended to decrease with the increase of milling degree and duration of storage (Table 8). The protein content in rice with milling degree of 85 and $100 \%$ during 3 months of storage were significantly different. They were 9.14 and $8.84 \%$, respectively. According to Juliano (1972) the decrease of milling degree decreased the nutritional content (including protein). Dharmaputra et al. (1993) reported that total protein in milled rice var. Cisadane decreased with the increase of milling degree.

At the beginning of storage the protein content in milled rice was $9.44 \%$, and then decreased to $9.18 \%$ at 3 months of storage. Dharmaputra et al. (1993) reported that the increase of storage duration decreased the protein content in milled rice. 
Table 8. The effect of milling degree, duration of storage, and interaction between milling degree and duration of storage on protein content of rice

\begin{tabular}{ccccccc}
\hline \hline \multirow{2}{*}{$\begin{array}{c}\text { Milling } \\
\text { degree (\%) }\end{array}$} & $\begin{array}{c}\text { Bag } \\
\text { type }\end{array}$ & \multicolumn{5}{c}{$\begin{array}{c}\text { Protein content (\%) } \\
\text { Duration of storage (month) }\end{array}$} \\
\cline { 3 - 7 } & & 0 & 1 & 2 & 3 & $\bar{x}$ \\
\hline 85 & $9.31 \mathrm{fg}$ & $8.85 \mathrm{~g}$ & $9.20 \mathrm{~g}$ & $9.20 \mathrm{~g}$ & $9.14 \mathrm{a}$ \\
90 & $9.77 \mathrm{f}$ & $9.13 \mathrm{~g}$ & $9.93 \mathrm{~g}$ & $9.34 \mathrm{fg}$ & $9.29 \mathrm{a}$ \\
95 & $9.40 \mathrm{fg}$ & $8.81 \mathrm{gh}$ & $9.03 \mathrm{~g}$ & $9.25 \mathrm{fg}$ & $9.12 \mathrm{a}$ \\
100 & & $\begin{array}{c}8.29 \mathrm{fg} \\
\bar{y}\end{array}$ & $\begin{array}{c}8.28 \mathrm{~h} \\
\text { Jute }\end{array}$ & $* .89 \mathrm{~g}$ & $8.92 \mathrm{~g}$ & $8.84 \mathrm{~b}$ \\
& Polypropylene & $*$ & $*$ & $*$ & $*$ & $*$ \\
& & $9.44 \mathrm{c}$ & $8.77 \mathrm{~d}$ & $9.01 \mathrm{e}$ & $9.18 \mathrm{e}$ & $*$ \\
\hline
\end{tabular}

Numbers followed by the same letter do not differ significantly according to Tukey Multiple Range Test at 95\% confidence level

* Not significantly different

According to Sinha and Muir (1973), the decrease of protein content may also be caused by degradation of amino acid and non-protein nitrogen such as vitamin $\mathrm{B}$ andphospholipid. .

The lowest protein content was found in rice with milling degree of $100 \%$ after 1 month of storage $(8.28 \%$ ), while the highest was in rice with milling degree of $90 \%$ at the beginning of storage $(9.77 \%)$.

In general, the increase of milling degree and duration of storage decreased the protein content hi milled rice.

\section{Total lipid content}

According to Juliano (1976), brown rice contained $\pm 1.9 \%$ lipid, while milled rice contained $\pm 0.5 \%$ lipid. Pomeranz (1974) reported that lipid was convened into free fatty acid and glycerol with the aid of lipase enzyme during storage. This con version was accelerated with the existence of storage fungi because the fungi have high ly poly tic activity.

Based on statistical analysis, milling degree, duration of storage, and interaction between milling degree and duration of storage gave very significant differences on the total lipid content, while bag type and interaction among milling degree, bag type and duration of storage gave significant differences. Interaction between milling degree and bag type, and interaction between bag type and duration of storage did not give significant differences.

Total lipid content decreased with the increase of milling degree and duration of storage (Table 9). Total lipid content in milled rice with milling degree of 85, 90, 95 and $100 \%$ were 0.26 , $0.23,0.20$ and $0.15 \%$, respectively. Juliano (1972) reported; 
The effects of milling degree and type of bag on fungal infection - Okky Setyawati Dharmaputra

Table 9. The effect of milling degree, bag type, duration of storage, interaction between milling degree and duration of stor age, and interaction among milling degree, bag type and duration of storage on total lipid content of nee

\begin{tabular}{|c|c|c|c|c|c|c|}
\hline \multirow{2}{*}{$\begin{array}{c}\text { Milling } \\
\text { degree (\%) }\end{array}$} & \multirow{2}{*}{$\begin{array}{l}\text { Bag } \\
\text { type }\end{array}$} & \multicolumn{5}{|c|}{$\begin{array}{c}\text { Total lipid content }(\%) \\
\text { Duration of storage (month) }\end{array}$} \\
\hline & & 0 & 1 & 2 & 3 & $\bar{x}$ \\
\hline \multirow[t]{3}{*}{85} & Jute & $0.34 \mathrm{~s}$ & $0.31 \mathrm{st}$ & $0.20 w$ & 0.18 wxy & $*$ \\
\hline & Polypropylene & $0.34 \mathrm{~s}$ & $0.31 \mathrm{st}$ & $0.25 \mathrm{v}$ & 0.18 wxy & * \\
\hline & & $0.34 k$ & 0.311 & $0.23 n$ & $0.18 \mathrm{op}$ & $0.26 \mathrm{a}$ \\
\hline \multirow[t]{3}{*}{90} & Jute & $0.31 \mathrm{st}$ & 0.28 tuv & $0.18 w x y$ & 0.16 xyz & * \\
\hline & Pòlypropylene & $0.31 \mathrm{st}$ & $0.27 \mathrm{uv}$ & $0.19 w x$ & 0.15 yzAB & $*$ \\
\hline & & 0.311 & $0.28 \mathrm{~m}$ & 0.18 op & $0.16 \mathrm{pq}$ & $0.23 \mathrm{~b}$ \\
\hline \multirow[t]{3}{*}{95} & Jute & $0.29 \mathrm{tu}$ & $0.25 \vee$ & $0.16 \times y z$ & $0.12 \mathrm{ABCD}$ & $*$ \\
\hline & Polypropylene & $0.29 \mathrm{tu}$ & $0.25 \mathrm{v}$ & $0.14 \mathrm{ZABC}$ & $0.12 \mathrm{ABCD}$ & $*$ \\
\hline & & $0.29 \mathrm{kl}$ & $0.25 n$ & $0.15 \mathrm{q}$ & $0.12 \mathrm{r}$ & $0.20 c$ \\
\hline \multirow[t]{3}{*}{100} & Jute & $0.19 w x$ & 0.17 wxy & $0.11 \mathrm{CD}$ & $0.10 \mathrm{D}$ & $*$ \\
\hline & Polypropylene & $0.20 \mathrm{w}$ & 0.17 wxy & $0.12 \mathrm{ABCD}$ & $0.11 \mathrm{CD}$ & $*$ \\
\hline & & 0.19 op & $0.17 \mathrm{opq}$ & $0.11 \mathrm{r}$ & $0.11 \mathrm{r}$ & $0.15 \mathrm{~d}$ \\
\hline \multirow[t]{3}{*}{$\bar{y}$} & Jute & * & $*$ & * & $*$ & $0.20 \mathrm{e}$ \\
\hline & Polypropylene & * & * & * & $*$ & $0.21 \mathrm{f}$ \\
\hline & & $0.28 \mathrm{~g}$ & $0.25 \mathrm{~h}$ & $0.17 \mathrm{j}$ & $0.14 \mathrm{j}$ & \\
\hline
\end{tabular}

Numbers followed by the same letter do not differ significantly according to Tukey Multiple Range Test at $95 \%$ confidence level

* Not significantly different

that milling removes the embryo and the bran layer, therefore total lipid found in this pan will decrease.

Total lipid content of milled rice packed in jute bag $(0.20 \%)$ was lower than packed in polypropylene bag $(0.21 \%)$, but chemical analysis showed no significant difference.

Total lipid content in milled rice at the beginning of storage, and at 1, 2 and 3 months of storage were $0.28,0.25,0.17$ and $0.14 \%$, respectively.

Dharmaputra et al. (1993) reported that the increase of milling degree and duration of storage, decreased total lipid content. According to Pomeranz (1992) degradation of fat or oil in grains can be affected by several factors, such as 1) oxydative process which gives rancid odour and taste, and 2) hydrolytic process which results to free fatty acid and glycerol.

The lowest total lipid content was found in rice with milling degree of $100 \%$, packed in jute bag at 3 months of storage $(0.10 \%)$, while the highest was in rice with milling degree of $85 \%$, packed in jute bag and polypropylene bags at the beginning of storage ( $0.34 \%$ respectively). 


\section{Correlation between moisture content and total fungal population}

Based on statistical analysis, the m.c. and total fungal population were positively related with coefficient correlation $(r)=0.52$. The increase of m.c. increased total fungal population (Figure 3).

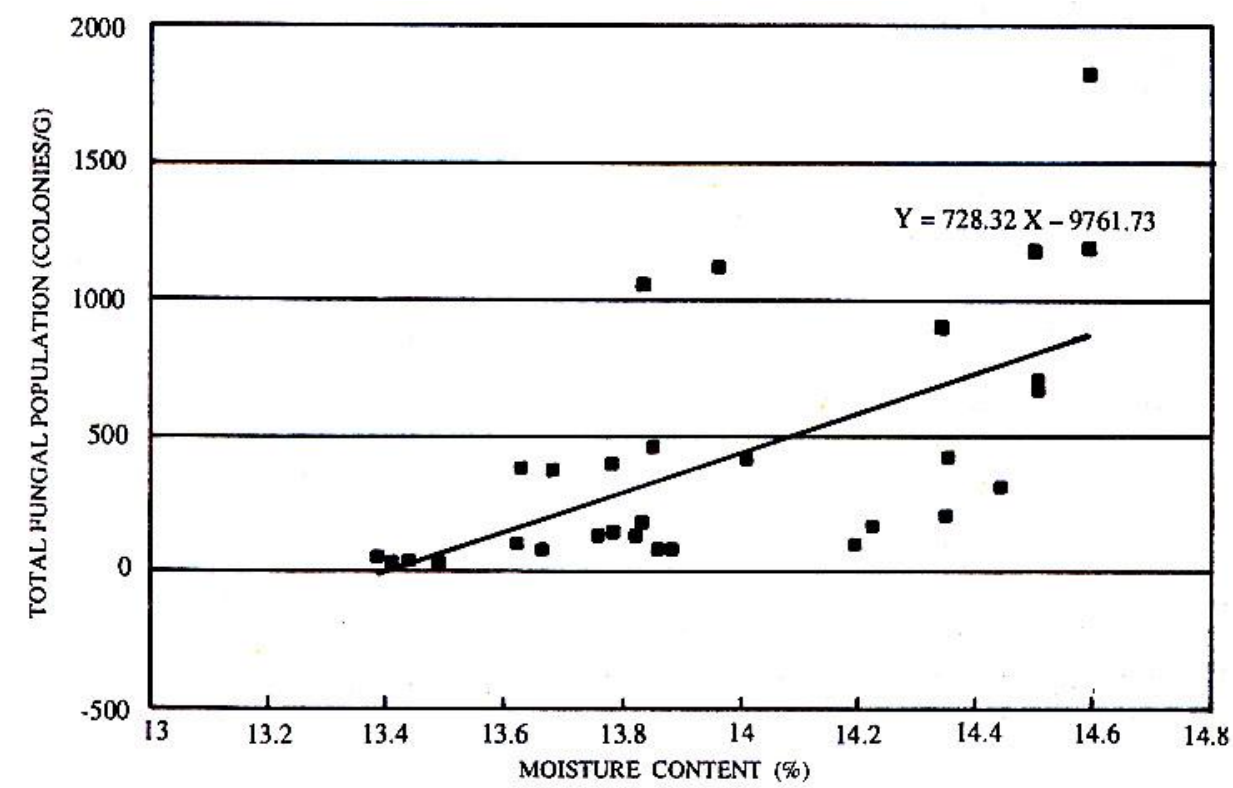

Figure 3. Correlation between moisture content and total fungal population on milled rice during storage

Water is required for the growth of fungi just as for other organisms. Fungi usually require a film of water around their cells through which nutrients and enzyme diffuse (Garraway and Evans 1984).

Ramakrishna et al. (1993) reported that spore germination and initial growth of fungi that infected the grain were affected by water activity and temperature of storage.

\section{Correlation between glucose content and total fungal population}

Statistical analysis showed no correlation between glucose content and total fungal population. It was assumed that glucose was not only used for the fungal nutrition, but also for respiration process of grains (Pomeranz 1992). 
The effects of milling degree and type of bag on fungal infection - Okky Setyawati Dbarmaputra

According to Garraway and Evans (1984) glucose is a good carbon source for 4-5 fungal species. Most of the fungal species also used oligosaccharide and polysaccharide as carbon source.

\section{Correlation between amylose content and total fungal population}

Based on statistical analysis, there was no correlation between amylose content and total fungal population. It was assumed that amylose was hydrolized into disaccharide by fungi-infected milled rice during storage. In this study twenty eight fungal species were isolated (Table 3). According to Garraway and Evans (1984) each fungal species may have different enzyme to hydrolize carbon sources, such as amylose.

\section{Correlation between protein content and total fungal population}

Statistical analysis showed no correlation between protein content and total fungal population. It was assumed that fungi require other nitrogen source for their growth and development. According to Garraway and Evans (1984) most fungi are able to utilize simple inorganic nitrogen sources as well as organic sources such as amino acids.

\section{Correlation between total lipid content and total fungal population}

Based on statistical analysis, the correlation between total lipid content and total fungal population was positive with $r=0.64$. The increase of total lipid content increased total fungal population (Figure 4).

Fungi contain a specific enzyme that could hydrolize lipid from the substrate for their development and growth (Patterson 1989). According to Garraway and Evans (1984), at first fungi hydrolized lipid with lipase enzyme, then changed them into glycerol through (3-oxidation pathway.

\section{CONCLUSIONS}

In this study the increase of milling degree and duration of storage, decreased the m.c. of rice. The type of bag did not give a significant difference on the m.c.

Twenty eight fungal species were isolated from rice with different milling degree and bag type during storage. Most of the fungi isolated belong to genera Aspergillus, Eurotium and Penicillium. The predominant species was A. candidus. 


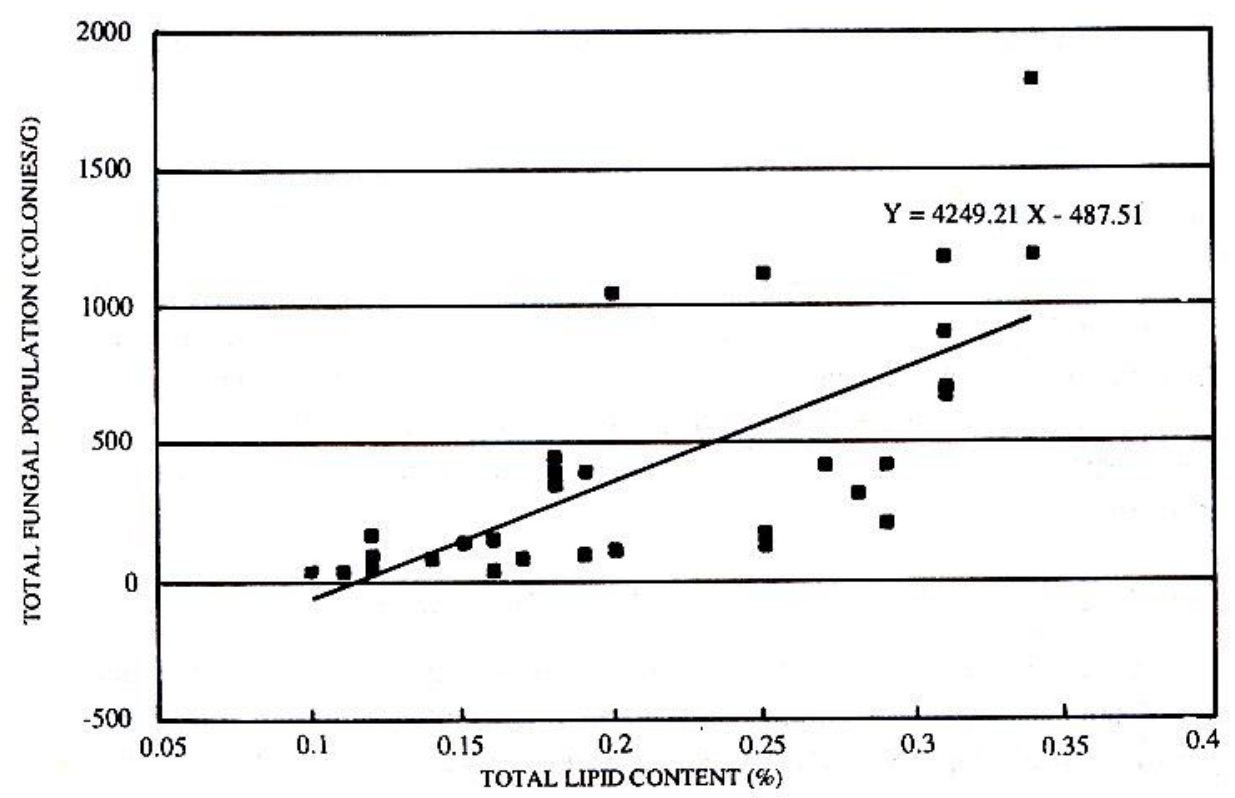

Figure 4. Correlation between total lipid content and total fungal population on milled rice during storage.

Total fungal population decreased with the increase of milling degree and duration of storage. Type of bag did not give a significant difference on the total fungal population.

Glucose content of milled rice increased with the increase of milling degree. When packed in jute bag the glucose content was higher than packed in polypropylene bag, but it decreased with the increase of storage duration.

Amylose content of milled rice increased with the increase of milling degree. When packed in jute bag the amylose content was lower than packed in polypropylene bag, but it decreased with the increase of storage duration.

Protein content in milled rice tended to decrease with the increase of milling degree and duration of storage, but it was not affected by bag type.

Total lipid content of milled rice decreased with the increase of milling degree and duration of storage. When packed in jute bag the lipid content differed significantly than packed in polypropylene bag, but chemical analysis showed no significant difference. 
The effects of milling degree and type of bag on fungal infection - Okky Setyawati Dharmiputn

Rice with low milling degree has high nutritional content, but it cannot be stored for long period. On the other hand rice with high milling degree has low nutritional content, but it can be stored for long period.

To get more information on the effect of bag type on fungal infection and chemical contents of stored milled rice, a research using stack of rice is needed.

\section{ACKNOWLEDGEMENT}

The author gratefully acknowledges the financial support of the Government of Indonesia. Thanks are due to Dr. Haryanto Susilo, Dr. Hariyadi Halid, Dr. Mulyo Sidik, Mr. Amad and Mrs. Asmarina S.R. Putri for their valuable assistance, and to Dr. A.D. Hocking from CSIRO, Australia, for the confirmation of fungal identification.

\section{REFERENCES}

BSI. 1980. Methods of Test for Cereals and Pulses. Pan 3. Determination of Moisture Content of Cereals and Cereal Products (Routine Method). British Standards Institution. ISBN 0058114333.

BULOG. 1994. Tatacara Teknis Pemenksaan Kualitas Gabah, Beras dan Karung Goni/Plastik dalam rangka Pengadaan Pangan dalam Negeri. Badan Urusan Logistik. Jakarta. (In Indonesian).

Christensen. C.M. and H.H. KAufmann. 1969. Grain Storage: the Role of Fungi in Quality Loss. University of Minnesota, Minneapolis.

_-_. 1974. Microflora. In C.M. Chrstensen (ed.). Storage of Cereal Grains and Their Product. American Association of Cereal Chemist., Inc. Minnesota, pp. 158-192.

DHARMAPUTRA, O.S. 1994. Kapang pada beras yang berasal dari beberapa varietas padi. Hayati 1(2): 37-41.

_-_. H. Halid, H. Susilo and A.S.R. Putri. 1993. The effects of milling degree on fungal infection, protein and total lipid content in milled rice. Proceeding 16th ASEAN Seminar on Grain Postharvest Technology, Phuket, Thailand. 24-26 August 1993.

OARRAWAY. M.O. and R.C. EVANS. 1984. Fungal Nutrition and Physiology. John Willey \& Sons Inc., New York.

GRIST. D.H. 1959. Rice $3^{\text {rd }}$ ed. Longmans, London.

JuLiano, B.O. 1972. Rice caryopsis and its composition. In D.F. Houston (ed). Rice Chemistry and Technology. American Association of Cereal Chemist., Minnesota.

_. 1976. The chemical basis of rice grain quality. Proceedings of the Workshop on Chemical Aspect of Rice Grain Quality. IRR1. Los Banos, Philippines.

_. A.A. ANTONIO and B.V. ESMAMA 1973. Effects of protein content on the distribution and properties or rice protein. J. Sci. Food Agr. 24: 295-306.

MAYES. P.A. 1981. Carbohydrate. In D.W. Martin, P.A. Mayes and V.W. Rodwell (ed). 18th Edition. Harper's Review of Biochemistry. Lange Medical Publication, Los Altos, California.

MOORE LANDECKER, E. 1982. Fundamentals of the Fungi. 2rd Edition. Prentice-Hall, Inc., New Jersey.

MUIR. W.E. 1973. Temperature and moisture in grain storage. In R.N. Sinha and W.E. Muir (ed). Grain Storage: Part a System. The Avi Publishing Company, Connecticut. 
PATterSON, H.B.W. 1989. Handling and Storage of Oilseeds, Oils, Fats and Meal. Elsevier Applied Science, New York.

Pitt, J.I. and A.D. Hocking. Fungi and Food Spoilage. Academic Press, Sydney.

POMERANZ. Y. 1992. Biochemical, functional and nutritive change during storage. In Sauer, D.B. (ed). Storage of Cereal Grains and Their Products. American Association of Cereal Chemist., Minnesota, pp. 55-141.

RAMAKRISHNA, N., J. LACEY and J.E. SMITH. 1993. Effects of water activity and temperature on the growth of fungi interacting on barley grain. Mycol. Res. 97(11): 1393-1402.

SAMSON, R.A., E.S. HOEKSTRA and C.A.N. vAN OORSCHOT. 1984. Introduction to Foodborne Fungi. Centraalbureau voor Schimmelcultures, Baam, The Netherlands.

SINHA. R.N. 1973. Interrelation of physical, chemical and biological variables in the deterioration of Stored grains. In R.N. Sinha and W.E. Muir («)). Grain Storage: Part a System. The Avi Publishing Co.

YoSHIDA, S., D.A. FORNO. J.H. COOK and K.A. GOMEZ. 1976. Laboratory Manual for Physiological Studies of Rice. IRRI, Los Banos, Philippines. 
